\title{
Az Európai Unió munkaerőpiaci helyzetének elemzése a koronavírus-válság idején
}

\section{Analysis of the Labour Market Situation in the European Union during the Coronavirus Crisis}

A 2019-ben jelentkező, majd 2020-ban globális kihivássá alakuló koronavírus-válság jelentôs hatással volt az egyes nemzetek munkaerôpiacának müködésére is. Jelen tanulmány a Covid-19 okozta pandémia időszakában veszi górcső alá az Európai Unió (EU) munkaerôpiaci helyzetét. A saját vizsgálataink keretei között szekunder kutatást végeztünk az Eurostat adatbázisára támaszkodva. Összefoglalva megállapitható, hogy a koronavírus-válság negativ hatással volt az Európai Unió tagállamainak munkaeröpiacára, átlagosan mintegy 1,2 százalékpontot rontva a vizsgált idöszakban az EU27 munkanélküliségi rátáján. Az összes vizsgált szektor esetében romlottak a foglalkoztatottsági mutatók. A tagállamok támogatása a munkahelyek megőrzésére a koronavírus első hulláma után volt a legintenzívebb.

Kulcsszavak: Covid-19, kormányzati intézkedések, koronavírus, válság, munkaerőpiac, Európai Unió

The coronavirus crisis, which occurred in 2019 and then turned into a global crisis in 2020, also had a significant impact on the functioning of the labour market. This study examines the labour market situation in the European Union during the period of the Covid-19 coronavirus epidemic. In our own studies, we conducted secondary research based on the Eurostat database. In summary, the coronavirus crisis had a negative impact on the labour markets of the EU Member States, worsening the EU27 unemployment rate by an average of around 1.2 percentage over the period under review. In all sectors examined, employment indicators deteriorated. Support for EU Member States to preserve jobs has been most intense since the first wave of the coronavirus.

Egyetemi docens, ELTE PPK Felnőttképzés-kutatási és Tudásmenedzsment Intézet. E-mail: karacsony. peter@ppk.elte.hu

PhD-hallgató, Selye János Egyetem Gazdaságtudományi és Informatikai Kar Közgazdaságtan Tanszék. E-mail: vivien.pasztoova97@gmail.com 
Keywords: Covid-19, governmental measures, coronavirus, crisis, labour market, European Union

\section{Bevezetés}

Napjaink egyik legnagyobb kihívása a Covid-19-vírus okozta válság hatékony kezelése. A Covid-19, vagyis a SARS-CoV-2 vírus által okozott járvány, hivatalos nevén új típusú koronavírus-járvány 2019 decemberében kezdődött a kínai Vuhan városában, majd cseppfertőzéssel terjedt tovább a világon. ${ }^{1}$ Kezdetben a Covid-19 járvány Kínára lokalizálódott, azonban az emberek mozgása révén gyorsan elterjedt az egész világon. A koronavírus-járvány az egészségügyi kockázatok mellett a nemzetek gazdaságára mérte a legnagyobb csapást. ${ }^{2} 2020$ első félévében a gazdasági tevékenység csaknem teljesen leállt a világon az egyes nemzeti kormányok által bevezetett szigorú védelmi intézkedések miatt. ${ }^{3}$ A koronavírus következtében az Európai Unió gazdasági növekedése 2020-ban és 2021-ben is jelentősen csökkent. Az Európai Bizottság jelentése szerint az EU gazdasága 2020-ban 6,3\%-kal csökkent, 2021-re pedig 3,8\%-os visszaesést prognosztizálnak. ${ }^{4} \mathrm{~A}$ gazdaság romlásával együtt az átlagos munkanélküliségi ráta $8,6 \%$ körül alakul 2021-ben, ami közel 3 százalékpontos növekedés az előző évhez képest. A Covid-19-válság következményei túlmutatnak a gazdaságra és a munkaerőpiacra gyakorolt hatásokon, ugyanis a koronavírus az uniós polgárok mindennapi életét szinte a felismerhetetlenségig megváltoztatta (például nőtt az elszigeteltség az egyes polgárok között, romlott a háztartások pénzügyi helyzete, bizonytalan és kiszámíthatatlan lett a jövő). A munkaidő csökkenése és a munkahelyek elvesztése következtében megnőtt a megélhetésért küzdő háztartások száma az Európai Unióban, egyre több háztartás halmoz fel fizetési hátralékot hitelek terén, ami tovább rontja a leginkább érintett, szegényebb társadalmi rétegek jövőbeli kilátásait. ${ }^{5}$

Jelen tanulmány célja, hogy megvizsgáljuk a Covid-19-válság hatásait az európai uniós munkaerőpiacra. Témaválasztásunkat a kialakult járványhelyzet indokolta. Kutatásunk jelentőségét abban látjuk, hogy ilyen jellegú és méretú járványra a modern piacgazdaságban még nem volt példa. Bár gazdasági világválsággal már többször is küzdött az emberiség, ugyanakkor az egészségügyi járványhelyzet által előidézett válság sokkal kiszámíthatatlanabb, mivel nem lehet előre megjósolni annak végét. Ezért a kutatásunkban arra kerestük a választ, hogy a koronavírus-válságnak milyen hatása volt/van az európai munkaerőpiacok alakulására. A tanulmány az Eurostat adatbázisából származó szekunder adatokra alapozva próbálja meg elemezni, hogy az Európai

Jeemol Unni: Impact of COVID-19 on Informal Economy: The Revival. The Indian Journal of Labour Economics, 63. (2020), S1. 113-118.

2 Pallah Nayak et al.: Impacts and Consequences of COVID-19 Epidemic on Global Economy. Coronaviruses, 2. (2021), 1. 77-88.

3 K. K. Zoidov - A. A. Medkov: Impact of the COVID-19 coronavirus pandemic and its control measures on the functioning of trade routes. Market Economy Problems, (2020), 2. 48-60.

Európai Bizottság: Autumn 2020 Economic Forecast (2020b).

Daphne Ahrendt et al.: Living, working and COVID-19: First findings - April 2020. Luxembourg, Publications Office of the European Union, 2020. 
Unió egyes tagállamainak főbb munkaerőpiaci mutatói hogyan alakultak a járvány megjelenése óta eltelt időszakban. A tanulmány megírásával további célunk volt a téma összefoglalása a magyar kutatók azon rétegének, amely az európai uniós munkaerőpiaci kutatások iránt érdeklődik.

\section{Elméleti háttér}

A közelmúlt eseményei alapjaiban rengették meg a hazai és a nemzetközi munkaerőpiacokat. A koronavírus-járvány féken tartása és annak gazdaságra gyakorolt negatív hatásai előre nem látható változásokat okoztak a munkaerőpiacokon. A legtöbb gazdaságban a járvány nem várt mértékű munkahelyelvesztést és az adott gazdaság recesszióját okozta. Annak érdekében, hogy ezeket a negatív következményeket könnyebben vészelhessék át az egyes gazdasági szereplők, a nemzeti kormányok, kénytelenek hatalmas pénzösszegeket fordítani a munkaerőpiaci politikára. ${ }^{6}$

Az Európai Unió tagállamait is magában foglaló Nemzetközi Munkaügyi Szervezet (ILO) szerint a járvány megjelenése rendkívüli mértékű munkanélküliséget és munkaerőpiacot érintő recessziót okoz majd a jövőre nézve is. Az egyes munkahelyeket érintő hatások nagyban függtek attól, hogy mennyire igényelt a munkavégzés személyes jelenlétet, ahol csak lehetett, a vállalatok áttértek a távmunka végzésére. ${ }^{7}$ A Covid-19válságra az egyes ágazatok eltérően reagáltak, attól függően, hogy milyen az adott ágazat alkalmazkodási jellemzője, valamint tartalékfelhalmozottsági szintje. A szociális távolságtartás következtében korlátozták az egyes szektorok működését, sőt volt olyan ágazat is (például szórakoztatóipar, turizmus), ahol szinte teljesen leállt a tevékenység a korlátozások bevezetésének következményeként. ${ }^{8}$ A legnagyobb kitettségú ágazatok közé tartozik a vendéglátóipar, az idegenforgalom, az egyéb szolgáltatások, valamint az autóipar. ${ }^{9} \mathrm{Az}$ autógyártás, mivel számos más ipari ágazathoz szorosan kapcsolódik, így a gazdasági fejlődés meghatározó része, széles körű összeköttetésben áll az upstream (acél, textil és vegyi anyagok) és a downstream (javítás, mobilitási szolgáltatások) ipari ágazatokkal. Az autóipar közel 14,6 millió európainak biztosít munkahelyeket, ami az EU teljes foglalkoztatásának 6,7\%-át jelenti. ${ }^{10} \mathrm{~A}$ másik jelentős mértékben érintett ágazat a turizmus és a vendéglátás volt. ${ }^{11} \mathrm{Az}$ idegenforgalom gazdasági szempontból az Európai Unió GDP-jének 10\%-át teszi ki, valamint megközelítőleg 2,4 millió vállalat érintett

6 Smriti Rao: Beyond the Coronavirus: Understanding Crises of Social Reproduction. Global Labour Journal, 12. (2021), 1. 39-53.

$7 \quad$ Seejeen Park - Yoon Jik Cho: Does telework status affect the behavior and perception of supervisors? Examining task behavior and perception in the telework context. The International Journal of Human Resource Management, (2020), 1-26.

8 Godwin-Charles Ogbeide: Pandemic (COVID-19) Implications: Recommendations for the Events and Tourism Industry. Events and Tourism Review, 3. (2020), 2. 32-38.

9 Fabian Hoeft: The case of sales in the automotive industry during the COVID-19 pandemic. Strategic Change, 30. (2021), 2. 117-125.

10 ACEA: Employment in the EU automotive industry (2020).

11 Catherine Cheung et al.: The impact of COVID-19 pandemic on the psychological needs of tourists: implications for the travel and tourism industry. Journal of Travel \& Tourism Marketing, 38. (2021), 2. $155-166$. 
a szektorban, amelyek 90\%-a kis- és középvállalkozások közé tartozik. ${ }^{12} \mathrm{~A}$ be- és kiutazási korlátozások jelentősen csökkentették az ágazatban tevékenykedők jövedelmét, ami a szektor foglalkoztatottságára is negatív hatással volt. Az Európai Bizottság jelentése a turizmus területén mintegy $60-80 \%$-os visszaesést mutatott ki, ami 840 milliárd és 1100 milliárd euró közötti exportbevétel-kiesést jelent a szektornak. ${ }^{13}$

A fent leírtak alapján elmondható, hogy a koronavírus hatása sokféleképpen jelentkezett az európai uniós munkaerőpiacon, tehát volt olyan szektor, amelyet leállásra vagy recesszióra kényszerített, ide főleg azok a gazdasági tevékenységek és ágazatok tartoznak, amelyek személyes jelenlétet követelnek meg a termeléshez, vagy azok, amelyek nagymértékben támaszkodnak a globális ellátási láncok inputjaira. ${ }^{14}$ Emellett volt olyan szektor is, amelyben a hagyományos munkavégzést felváltotta a távmunka, és így fenn tudták tartani a folyamatos múködést a digitalizációnak köszönhetően, ezzel csökkentve a munkanélküliség kockázatát. ${ }^{15}$ Végezetül volt olyan szektor (például az elektronikus kereskedelem, számítástechnika, élelmiszeripar), amelyre pozitív hatással volt a koronavírus-válság a szektor szolgáltatásai vagy termékei iránt megnövekedett kereslet miatt. ${ }^{16}$ Mindezekből következik, hogy az ágazati kitettség és a gazdasági tevékenységek közötti különbségek olyan strukturális tényezők, amelyek befolyásolják az egyének munkanélküliségi aggályait és kockázatait. ${ }^{17}$

Összefoglalóan elmondható, hogy a koronavírusnak hosszú távon hatása lesz az Európai Unió munkaerőpiacára. Ugyanakkor már az is látható, hogy az egyes szektorokat eltérően érinti, így még nagyobb egyenlőtlenségek alakulhatnak ki a munkaerőpiacon, lesznek egyértelmú vesztesei (ez idáig több millióan vesztették el munkahelyüket Európa-szerte) és nyertesei a válságnak, főleg azok, akik megfelelő technikai háttérrel rendelkeztek és olyan tevékenységet végeztek, amelyben gyorsan át lehetett állni a hagyományos munkavégzésről a távmunkára.

12 Európai Bizottság: A Bizottság Közleménye az Európai Parlamentnek, a Tanácsnak, az Európai Gazdasági és Szociális Bizottságnakés a Régiók Bizottságának: Turizmus és közlekedés 2020-ban és azon túl COM(2020) 550 végleges (2020a. május 13.).

13 Európai Bizottság: A Bizottság Közleménye az Európai Parlamentnek, a Tanácsnak, az Európai Gazdasági és Szociális Bizottságnakés a Régiók Bizottságának: Turizmus és közlekedés 2020-ban és azon túl COM(2020) 550 végleges (2020a. május 13.).

14 James R. Francis: COVID-19: Implications for Supply Chain Management. Frontiers of Health Services Management, 37. (2020), 1. 33-38.

15 A. Angeloska - E. Spaller - L. Vasa: Foreign direct investment, digital skills and employability - comparison between Eastern and Western Europe. In Marcel Kordoš: Proceedings of scientific papers from the international scientific conference „The Impact of Industry 4.0 on Job Creation 2020”. Trenčín, Publishing House Alexander Dubček University, 2020. 30-37; Jean-Victor Alipour - Harald Fadinger - Jan Schymik: My Home Is my Castle - The Benefits of Working from Home during a Pandemic Crisis: Evidence from Germany. CEPR Discussion Paper 14871, 2020; Imre Vida - Endre Spaller - László Vasa: Potential effects of finance 4.0 on the employment in East Africa. Economy and Sociology/Economie si Sociologie, (2020), 2. 29-42.

16 Balázs Gyenge et al.: A New Strategic Marketing Management Model for the Specificities of E-Commerce in the Supply Chain. Journal of Theoretical and Applied Electronic Commerce Research, 16. (2021), 4. 1136-1149.

17 Marcin Wolski - Patricia Wruuck: COVID-19 and the EU labour market: Corporate health matters. Vox. eu, (2020. augusztus 5.). 


\section{Módszertan}

A saját kutatásunk szekunder kutatás, amely az Eurostat adatbázisára támaszkodik elsősorban. A következőkben a 2020-2021-es időszakot vizsgáljuk meg, mintegy áttekintést adva az EU munkaerőpiaci helyzetének alakulásáról a koronavírus-járvány idején. $\mathrm{Az}$ egyes diagramokat a Microsoft Excel táblázatkezelő program segítségével készítettük el. Az eredmények bemutatása során törekedtünk azon adatok külön kiemelésére, amelyek jelentős mértékben eltértek a korábbi évekhez képest. Az adatok elemzésére egyszerű összehasonlító (komparatív) módszertant használtunk fel.

\section{Saját vizsgálatok eredményei}

A következőkben az összehasonlító elemzéseink legfontosabb eredményeit mutatjuk be részletesen.

1. táblázat

A foglalkoztatottsági ráta változása az előző időszakhoz viszonyítva az egyes európai uniós tagállamokban, százalékosan

\begin{tabular}{|c|c|c|c|c|c|}
\hline & $\mathbf{2 0 1 9 - Q 4}$ & $\mathbf{2 0 2 0 - Q 1}$ & $\mathbf{2 0 2 0 - Q 2}$ & $\mathbf{2 0 2 0 - Q 3}$ & $\mathbf{2 0 2 0 - Q 4}$ \\
\hline EU27 & 0,1 & $-0,1$ & $-2,7$ & 0,9 & 0,4 \\
\hline Belgium & 0,4 & $-0,2$ & $-0,8$ & 0,2 & 0,4 \\
\hline Bulgária & 0,4 & $-0,9$ & $-1,0$ & $-0,5$ & $-0,4$ \\
\hline Csehország & $-0,2$ & 0,0 & $-1,5$ & 0,2 & $-0,5$ \\
\hline Dánia & 0,1 & $-0,1$ & $-2,2$ & 1,3 & 0,4 \\
\hline Németország & 0,1 & 0,0 & $-1,5$ & $-0,2$ & 0,0 \\
\hline Észtország & 1,2 & $-0,5$ & $-5,1$ & $-0,2$ & 1,9 \\
\hline Írország & 1,5 & 0,0 & $-6,0$ & 3,2 & 0,3 \\
\hline Görögország & $-0,3$ & 0,3 & $-2,8$ & 1,2 & $-0,1$ \\
\hline Spanyolország & 0,7 & $-1,0$ & $-7,5$ & 3,0 & 1,2 \\
\hline Franciaország & 0,3 & $-0,1$ & $-2,8$ & 1,3 & 0,2 \\
\hline Horvátország & 0,7 & $-0,1$ & $-1,5$ & $-0,4$ & $-0,5$ \\
\hline Olaszország & $-0,4$ & $-0,6$ & $-2,4$ & 0,7 & 0,3 \\
\hline Ciprus & 0,0 & $-0,1$ & $-0,9$ & $-0,3$ & $-0,2$ \\
\hline Lettország & 0,2 & $-0,1$ & $-4,5$ & 1,7 & $-0,5$ \\
\hline Litvánia & 0,3 & 0,7 & $-2,1$ & $-1,2$ & 0,5 \\
\hline Luxemburg & 0,9 & 0,3 & $-0,5$ & 1,3 & 0,6 \\
\hline Magyarország & 0,0 & $-0,4$ & $-4,4$ & 2,6 & 0,9 \\
\hline Málta & 1,7 & 0,6 & $-0,5$ & 0,0 & $-0,5$ \\
\hline
\end{tabular}




\begin{tabular}{|c|c|c|c|c|c|}
\hline & $\mathbf{2 0 1 9 - Q 4}$ & $\mathbf{2 0 2 0 - Q 1}$ & $\mathbf{2 0 2 0 - Q 2}$ & $\mathbf{2 0 2 0 - Q 3}$ & $\mathbf{2 0 2 0 - Q 4}$ \\
\hline Hollandia & 0,4 & 0,2 & $-2,8$ & 1,6 & $-0,1$ \\
\hline Ausztria & 0,3 & $-0,2$ & $-4,3$ & 2,9 & 0,0 \\
\hline Lengyelország & $-0,6$ & 0,8 & $-1,2$ & 0,6 & 0,9 \\
\hline Portugália & $-0,1$ & $-0,2$ & $-3,5$ & 1,3 & 1,9 \\
\hline Románia & $-0,1$ & 0,5 & $-2,3$ & $-0,4$ & 0,5 \\
\hline Szlovénia & 0,2 & 0,2 & $-2,3$ & 0,3 & 0,4 \\
\hline Szlovákia & 0,2 & 0,3 & $-1,3$ & 0,1 & 0,4 \\
\hline Finnország & 0,2 & $-0,2$ & $-2,9$ & 1,0 & 0,6 \\
\hline Svédország & 0,0 & $-0,3$ & $-2,0$ & 0,5 & 0,5 \\
\hline
\end{tabular}

Forrás: a szerzők szerkesztése az Eurostat 2021-es adatai alapján (adatok elérhetősége: https:// ec.europa.eu/eurostat/databrowser/view/t2020_10/default/table?lang=en)

A fenti, 1. táblázat a foglalkoztatási mutatókat szemlélteti a koronavírus-járvány kirobbanása előtti 2019-es év utolsó negyedévétől kezdődően. Az adatok az előző időszakhoz viszonyított változást százalékos formában, kortól és nemtől függetlenül mutatják be. A táblázat adatai szerint a koronavírus első hulláma (2020-Q2) volt a legnagyobb hatással a foglalkoztatottság alakulására, az adatok szerint az összes vizsgált európai uniós országban csökkent a foglalkoztatottsági mutató az előző időszakhoz képest. Egyes uniós tagállamok esetében a negatív irányú változás egészen magas százalékot tett ki, ilyen volt Írország (-6\%), Spanyolország (-7,5\%), Észtország (-5,1\%), Magyarország $(-4,4 \%)$, Ausztria $(-4,3 \%)$ vagy Portugália $(-3,5 \%)$ is. A második hullámra (2020-Q4) valamelyest rendeződött a helyzet, és a változások egyes tagállamok esetében pozitív irányban is elmozdultak, ezen időszakban a legnagyobb arányú növekedést Észtország (1,9\%) és Portugália (1,9\%) érte el. Kisebb arányban, mint az első hullámban, de tovább csökkent a foglalkoztatottsági mutatója például Csehországnak (-0,5\%), Horvátországnak (-0,5\%), Lettországnak (-0,5\%) és Máltának (-0,5\%) is. A pozitív irányú változás egyértelmúen a tagállamok által nyújtott támogatásoknak és a különböző munkahelyvédelmi akcióterveknek volt köszönhető, ezek nélkül valószínűsíthető, hogy jóval nagyobb arányú lett volna a csökkenés a foglalkoztatottsági mutatókban.

A továbbiakban az egyes ágazatokra jellemző foglalkoztatottsági ráta adatainak alakulását mutatjuk be röviden (2. táblázat). Mindegyik esetben a járvány előtti 2019-es év 4. negyedévét vettük kiindulási pontnak, és ehhez hasonlítottuk a 2020-as év 4. negyedévének adatait. A mezőgazdaság, halászat és erdészet ágazatban a 2019-es év utolsó negyedévében a foglalkoztatási ráta pozitív irányú változásának legnagyobb értéke Bulgáriára (5,4\%) volt érvényes, ezt követte Svédország (4,1\%) és Írország (3,9\%). Litvánia (-8,1\%), Észtország (-7,5\%) és Horvátország (-5,3\%) esetében pedig a legnagyobb negatív irányú változás zajlott le a 2019-es év végén. A 2020-as év 4. negyedévének adatait vizsgálva Észtországban jelentős javulás volt észlelhető, ugyanis 8,3\%-kal emelkedett a mezőgazdasági, halászati és erdészeti ágazat foglalkoztatási rátája, illetve Portugáliában (7,1\%) volt még jelentősebb pozitív irányú változás. A negatív irányú 
változások színhelyei közül kiemelendő Magyarország, ahol a mezőgazdaságot, halászatot, erdészetet érintő foglalkoztatási ráta $0,7 \%-k a l$ csökkent.

A kereskedelem, szállítás és vendéglátás foglalkoztatottsági rátájának változásait elemezve 2019 utolsó negyedévében Írország foglalkoztatási rátája nőtt a legnagyobb mértékben, 1,8\%-kal, amit Málta 1,6\%-os, illetve Spanyolország 1,4\%-os emelkedése követett. A negatív irányú változás Litvániára $(-1,4 \%)$ és Ciprusra $(-1,1 \%)$ volt érvényes. Ugyanezen adatokat megvizsgálva a 2020-as év utolsó negyedévében némi javulás volt tapasztalható többek között Bulgária (2,8\%) és Horvátország (1,4\%) esetében, míg a legnagyobb csökkenés Írország (-1,3\%), Málta (-1,0\%) és Görögország $(-0,7 \%)$ esetében volt megfigyelhető.

A közigazgatás, oktatás, egészségügy és szociális ágazatok terén 2019 utolsó negyedévében Málta (1,2\%) és Luxemburg (1,1\%) esetében nőtt e szektor foglalkoztatottsági rátája, miközben Lengyelországban (-2,3\%), illetve Bulgáriában (-1,2\%) csökkent. A 2020-as év utolsó negyedévét megvizsgálva a szektor foglalkoztatottsági rátájában a legnagyobb arányú pozitív növekedés Észtországban (2,6\%) és Spanyolországban $(2,5 \%)$ volt megfigyelhető, míg a csökkenés Horvátországot $(-4,0 \%)$, Romániát $(-1,9 \%)$ és Görögországot (-0,9\%) érintette leginkább.

Az ipari ágazatokat megvizsgálva 2019 utolsó negyedévében Litvániában 5,1\% volt a szektor foglalkoztatottsági rátájának növekedése, amit Horvátország követett 1,6\%-kal. Ezen időszakban a legnagyobb arányú csökkenést Észtország (-1,6\%) és Csehország (-1,5\%) produkálta. A 2020 utolsó negyedévében Románia esetében nőtt a legnagyobb arányban, 3,1\%-kal az ipari szektor foglalkoztatottsági rátája, ezt követte Lengyelország (2,1\%), Portugália (1,8\%), Írország (1,5\%) és Spanyolország (1,3\%). Ezzel szemben az ipari szektor foglalkoztatottsági rátájának csökkenése 2020-as év 4. negyedévében Bulgáriát, Észtországot és Görögországot egyaránt -1,3\%-kal érintette.

A kapott eredmények alapján kijelenthető, hogy az egyes szektorokat különböző mértékben érintette a koronavírus-válság.

2. táblázat

Az egyes szektorok foglalkoztatottsági rátájának változása az előző időszakhoz viszonyítva, százalékosan

\begin{tabular}{|c|c|c|c|c|c|c|c|c|}
\hline & \multicolumn{2}{|c|}{$\begin{array}{l}\text { Mezőgazdaság, } \\
\text { halászat, } \\
\text { erdészet }\end{array}$} & \multicolumn{2}{|c|}{$\begin{array}{l}\text { Kereskedelem, } \\
\text { szállítás és } \\
\text { vendéglátás }\end{array}$} & \multicolumn{2}{|c|}{$\begin{array}{l}\text { Közigazgatás, okta- } \\
\text { tás, egészségügy és } \\
\text { szociális ágazatok }\end{array}$} & \multicolumn{2}{|c|}{ Ipari ágazatok } \\
\hline & 2019-Q4 & 2020-Q4 & 2019-Q4 & 2020-Q4 & 2019-Q4 & 2020-Q4 & 2019-Q4 & 2020-Q4 \\
\hline EU-27 & $-0,1$ & 0,2 & 0,3 & $-0,1$ & 0,1 & 0,6 & $-0,4$ & 0,4 \\
\hline Belgium & 0,5 & $-0,2$ & 0,4 & $-0,1$ & 0,4 & 0,5 & 0 & 0,1 \\
\hline Bulgária & 5,4 & 0 & $-0,4$ & 2,8 & $-1,2$ & $-0,3$ & $-0,5$ & $-1,3$ \\
\hline Csehország & -1 & $-1,2$ & $-0,2$ & $-2,7$ & 0,5 & $-0,1$ & $-1,5$ & $-0,9$ \\
\hline Dánia & 0,2 & $-0,5$ & 0,4 & $-1,2$ & 0,1 & 1,5 & $-0,8$ & 0,6 \\
\hline Németország & $-0,3$ & $-1,6$ & 0,2 & $-0,4$ & 0,5 & 0,5 & $-0,4$ & $-0,3$ \\
\hline Észtország & $-7,5$ & 8,3 & 1,1 & $-0,5$ & $-0,2$ & 2,6 & $-1,6$ & $-1,3$ \\
\hline Írország & 3,9 & 3,4 & 1,8 & $-1,3$ & 0,7 & 0,4 & $-0,5$ & 1,5 \\
\hline
\end{tabular}




\begin{tabular}{|c|c|c|c|c|c|c|c|c|}
\hline & \multicolumn{2}{|c|}{$\begin{array}{c}\text { Mezögazdaság, } \\
\text { halászat, } \\
\text { erdészet }\end{array}$} & \multicolumn{2}{|c|}{$\begin{array}{c}\text { Kereskedelem, } \\
\text { szállitás és } \\
\text { vendéglátás }\end{array}$} & $\begin{array}{c}\text { Közigazgatás, okta- } \\
\text { tás, egészségügy és } \\
\text { szociális ágazatok }\end{array}$ & \multicolumn{2}{|c|}{ Ipari ágazatok } \\
\hline & $\mathbf{2 0 1 9 - Q 4}$ & $\mathbf{2 0 2 0 - \mathbf { Q 4 }}$ & $\mathbf{2 0 1 9 - \mathbf { Q 4 }}$ & $\mathbf{2 0 2 0 - \mathbf { Q 4 }}$ & $\mathbf{2 0 1 9 - Q 4}$ & $\mathbf{2 0 2 0 - Q 4}$ & $\mathbf{2 0 1 9 - Q 4}$ & $\mathbf{2 0 2 0 - Q 4}$ \\
\hline Görögország & $-1,9$ & 0,8 & 0,9 & $-0,7$ & 0,8 & $-0,9$ & $-1,3$ & $-1,3$ \\
\hline Spanyolország & $-1,2$ & $-0,7$ & 1,4 & 0,3 & 0,6 & 2,5 & $-0,4$ & 1,3 \\
\hline Franciaország & $-0,4$ & 1,2 & 0,5 & 0,1 & 0, & $-0,2$ & 0, & $-0,6$ \\
\hline Horvátország & $-5,3$ & 1,8 & $-0,1$ & 1,4 & 0,9 & -4, & 1,6 & 0,4 \\
\hline Olaszország & 3, & $-0,7$ & $-0,8$ & 0,6 & 0, & 0, & $-0,3$ & 0,2 \\
\hline Ciprus & 0,1 & $-0,2$ & $-1,1$ & $-0,3$ & 0,6 & 0, & 0,7 & $-0,2$ \\
\hline Lettország & $-1,4$ & 0, & 0,7 & $-1,2$ & 0,2 & 0,1 & $-0,7$ & 0,2 \\
\hline Litvánia & $-8,1$ & 1,5 & $-1,4$ & 1, & 0,5 & $-0,1$ & 5,1 & $-0,1$ \\
\hline Luxemburg & $-0,3$ & $-1,8$ & 0,7 & $-0,1$ & 1,1 & 0,9 & 0,1 & $-0,3$ \\
\hline Magyarország & 0,1 & $-0,7$ & 0,3 & 1, & 0, & 0, & $-0,2$ & 1,1 \\
\hline Málta & 0,2 & $-0,4$ & 1,6 & -1, & 1,2 & $-0,4$ & 0,6 & $-0,3$ \\
\hline Hollandia & 0,5 & 0,5 & 0,3 & $-2,2$ & 0,8 & 0,9 & 0,2 & $-0,1$ \\
\hline Ausztria & $-0,1$ & $-0,1$ & 0,4 & $-2,4$ & 0,2 & 1,3 & 0,2 & 0,3 \\
\hline Lengyelország & $-0,4$ & 3,7 & 1, & 0,2 & $-2,3$ & 1,4 & $-0,5$ & 2,1 \\
\hline Portugália & -2, & 7,1 & 0,3 & $-0,3$ & 0,4 & 1,3 & $-0,4$ & 1,8 \\
\hline Románia & $-0,4$ & $-3,3$ & 0, & 3, & 0,3 & $-1,9$ & $-0,9$ & 3,1 \\
\hline Szlovénia & $-0,4$ & $-0,5$ & 0,2 & $-0,2$ & 0,5 & 0,6 & $-0,1$ & 0,7 \\
\hline Szlovákia & $-0,2$ & $-0,3$ & 0,1 & $-0,2$ & 0,3 & 0,2 & $-0,2$ & 0,1 \\
\hline Finnország & 1,3 & 6,5 & 0,2 & $-0,6$ & 0,2 & 0,3 & $-0,8$ & 0,7 \\
\hline Svédország & 4,1 & -1, & $-0,2$ & 0,6 & $-0,2$ & 0,1 & $-0,8$ & 0,6 \\
\hline
\end{tabular}

Forrás: a szerzők szerkesztése az Eurostat 2021-es adatai alapján (https://ec.europa.eu/eurostat/ databrowser/view/TEC00108/bookmark/table?lang=en\&bookmarkId=fdf7160b-19e2-45c3-9b1

9-dcfd993209db)

Az alább következő, 1. ábra az EU 27 tagállama munkanélküliségi rátájának alakulását mutatja be a vizsgált időszakra vonatkozóan. A rajta szereplő adatok százalékos formában vannak megadva, és ahol elérhető volt a 2021-es év első negyedévére vonatkozó adat, ott azt is feltüntettük.

2019-es év végén, a koronavírus-járvány európai elterjedése előtti időszakban a legrosszabb munkanélküliségi adatokkal Görögország $(16,8 \%)$ rendelkezett, ezt követte Spanyolország (13,6\%), majd Olaszország (10\%). Ezen időszakban az európai uniós tagállamok közül Csehországban volt a legkisebb a munkanélküliségi ráta, 1,9\%. A koronavírus-járvány kitörése után egy évvel, azaz 2020 decemberében Görögország (16,3\%) csekély javulást mutat, de még mindig itt a legmagasabb a munkanélküliségi ráta, amelyhez kezd egyre jobban Spanyolország $(16,1 \%)$ is felzárkózni, ahol is közel 3\%-os romlás figyelhető meg a munkanélküliségi rátában 1 év alatt. További jelentős növekedés volt 
megfigyelhető ezen időszakban többek között Litvánia (9,5\%), Svédország (8,2\%), Horvátország (7,9\%), Finnország (7,8\%), Szlovákia (7,1\%), Észtország (6,8\%), Ausztria (6,1\%) és Románia (5,3\%) esetében. A 2021-es évből rendelkezésre álló adatokból látható, hogy Spanyolországban (16,4\%), Svédországban (9,3\%) további növekedés volt tapasztalható a munkanélküliségi ráta terén, ahogy Magyarországon (5,0\%), Romániában (5,8\%) és Horvátországban (8,3\%) is. A többi ország esetében kisebb-nagyobb pozitív és negatív elmozdulások érzékelhetők.

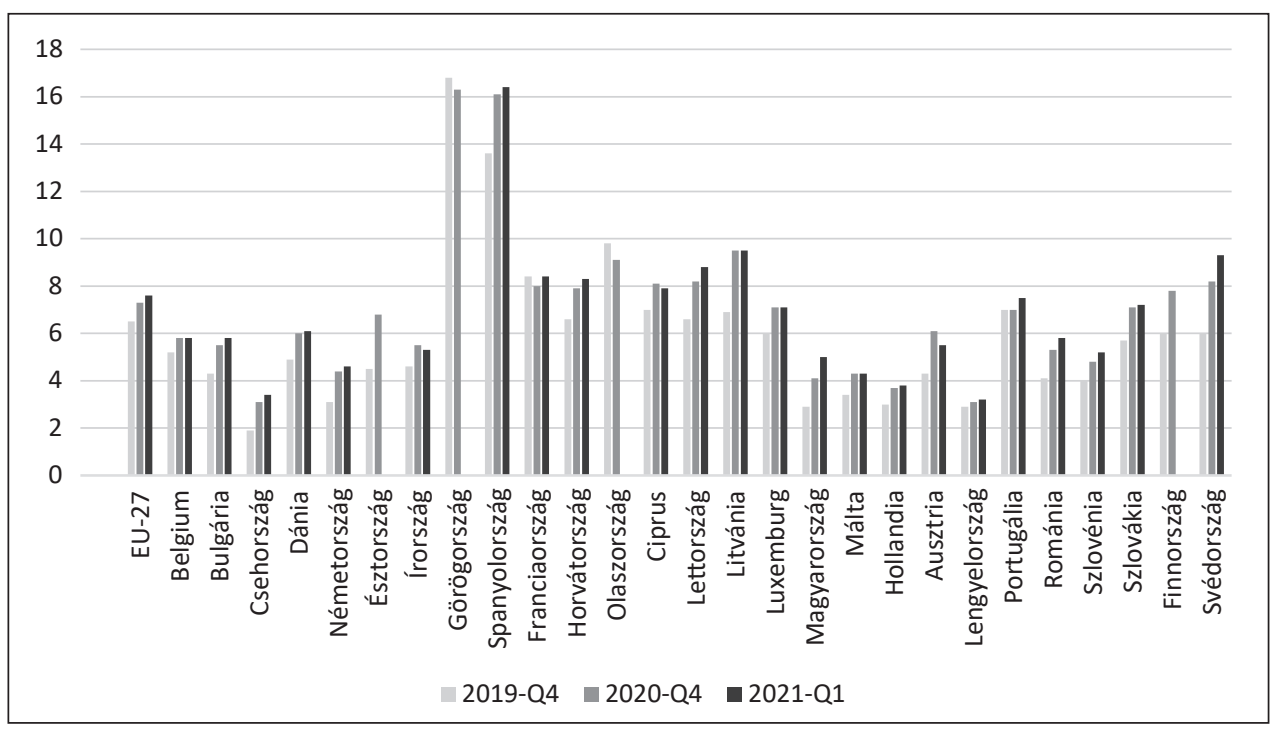

1. ábra

A munkanélküliségi ráta alakulása a vizsgált időszakban az Európai Unió egyes tagállamaiban, százalékosan

Forrás: a szerzők szerkesztése az Eurostat 2021-es adatai alapján (https://ec.europa.eu/eurostat/ databrowser/view/une_rt_m/default/table?lang=en)

A fenti adatok alapján elmondható, hogy a koronavírus következtében az Európai Unió 27 tagállamában romlottak a munkanélküliségiráta-adatok, összességében az EU27ben, mintegy 1,2\%-kal lett magasabb a munkanélküliségi ráta a korábbi évhez képest.

A munka termelékenységét és egységnyi munkaerőköltségét az európai uniós statisztikákban az egy főre eső valódi munka termelékenységével fejezzük ki. A következő, 2. ábra mutatja be, hogyan változott a munka termelékenysége és egységnyi munkaerőköltsége az Európai Unió egyes tagállamaiban a vizsgált időszakban. A vizsgált időszakban a munka termelékenysége és egységnyi munkaerőköltsége Észtország, Lettország, Litvánia és Románia esetében nőtt kisebb mértékben, míg a többi európai uniós tagállamban csökkent. Az Európai Unió tagállamai közül Romániában a legnagyobb az egy főre eső valódi munka termelékenysége $(165,2)$, míg Görögország esetében $(84,8)$ a legkisebb, az európai uniós átlag pedig 106,9. 


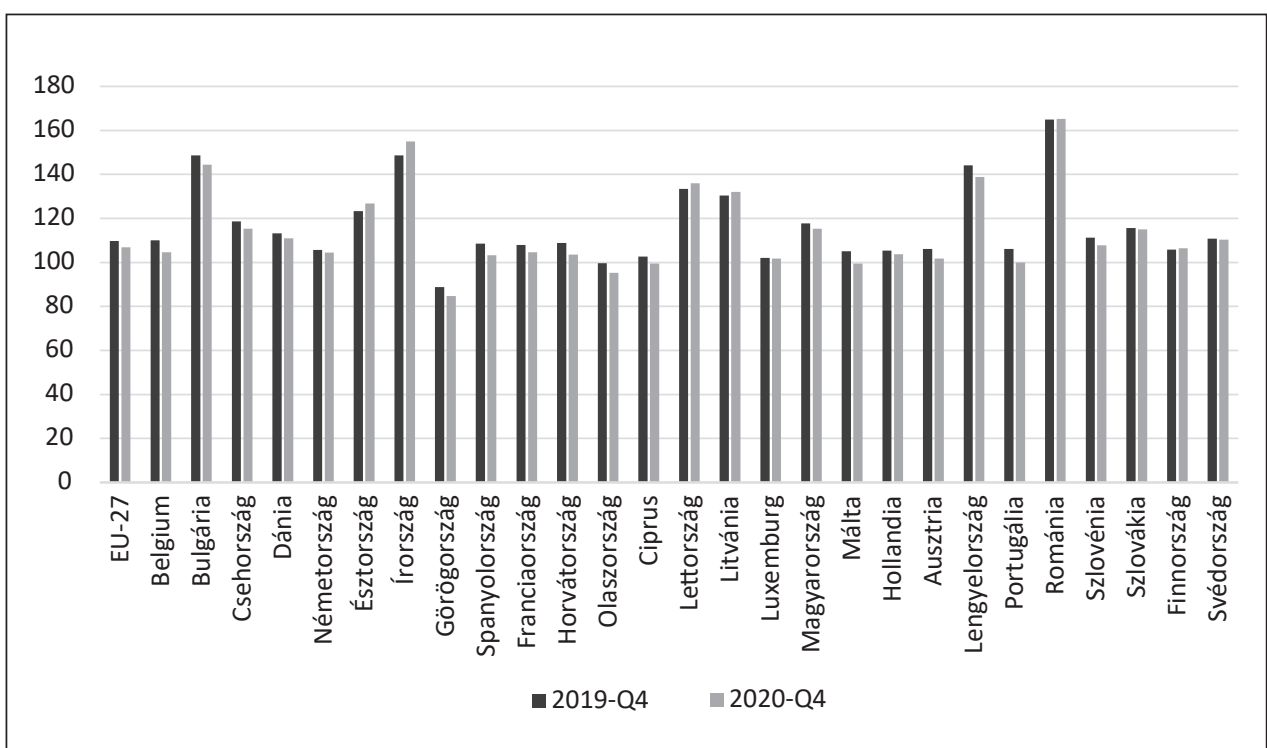

2. ábra

A munka termelékenységének és egységnyi munkaerőköltségének alakulása az Európai Unió egyes tagállamaiban, az egy före esô valódi munka termelékenysége szerint

Forrás: a szerzők szerkesztése az Eurostat 2021-es adatai alapján (https://ec.europa. eu/eurostat/databrowser/view/teilm140/default/table?lang=en)

A világjárvány okozta gazdasági és társadalmi nehézségek elleni küzdelemhez az uniós vezetők egy rendkívüli, 750 milliárd euró összegű helyreállítási alap - az úgynevezett „Next Generation EU” - felállításáról döntöttek. A helyreállítási csomagból elsősorban a digitális és a zöld átállást segítő beruházások kaphatnak majd támogatást. Az Európai Tanács emellett megállapodott az EU 2021 és 2027 közötti időszakra szóló hosszú távú költségvetéséről, amely az elkövetkező években elősegíti majd a növekedést, valamint támogatja a polgárokat, a vállalkozásokat és a gazdaságokat. Továbbá a munkavállalók megsegítése érdekében az EU létrehozott egy olyan eszközt (SURE), amely szükséghelyzetben ideiglenes támogatást nyújt a munkanélküliségi kockázatok mérsékléséhez. A SURE mint európai eszköz tehát azzal a céllal jött létre, hogy segítse az embereket munkahelyük megtartásában a válság idején. Az eszköz keretében a tagállamok kedvező feltételekkel juthatnak hitelhez, hogy fedezni tudják a csökkentett munkaidőben való foglalkoztatás nemzeti szintű bevezetéséhez vagy kibővítéséhez kapcsolódó költségek egy részét. Ez idáig 18 tagállam összesen 90,3 milliárd euró pénzügyi támogatást kapott a program keretében (3. ábra). A támogatási programot a legnagyobb mértékben Olaszország (27, 4 milliárd euró), Spanyolország (21,3 milliárd euró) és Lengyelország (11,2 milliárd euró) vette igénybe. Magyarország 5,4 millió euró támogatási összeget vett igénybe a programból. 


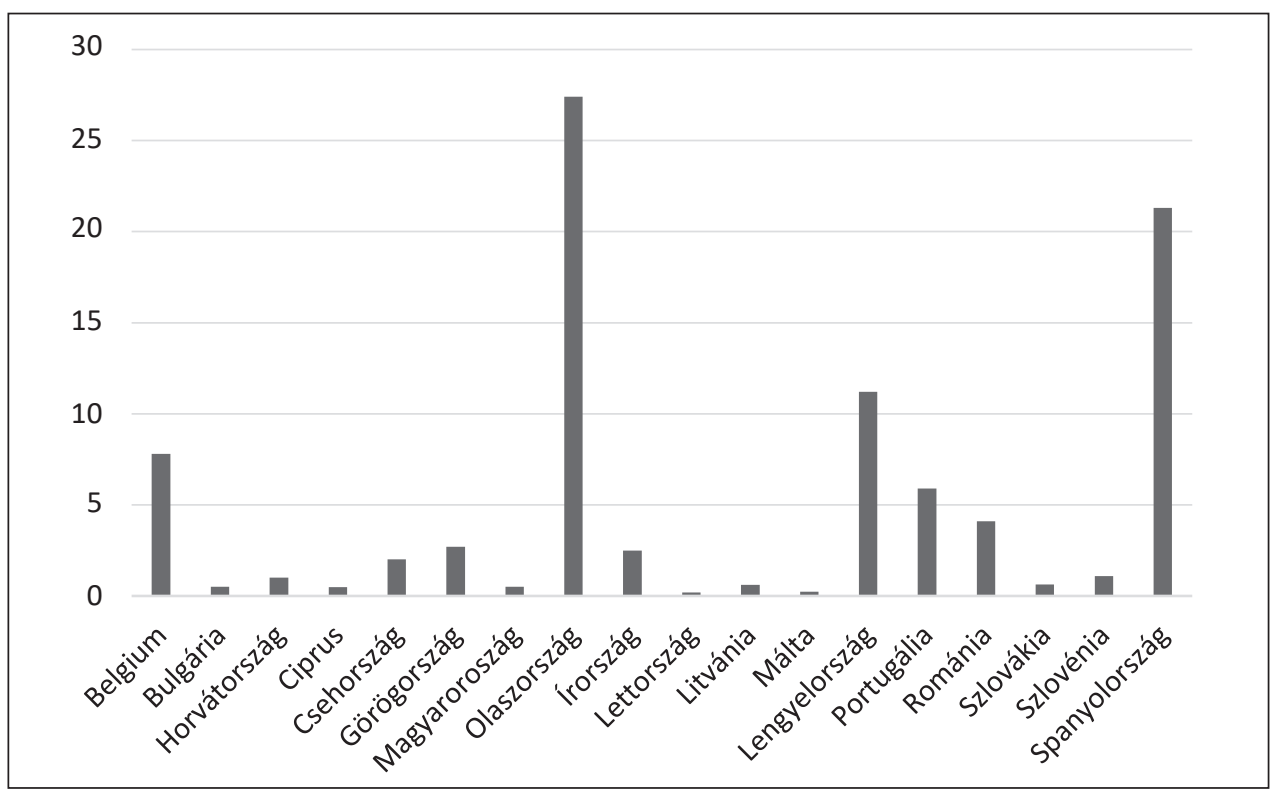

3. ábra

A SURE program keretében lehivott támogatások összege tagállamonként, milliárd euróban

Forrás: a szerzők szerkesztése az Európai Unió Tanácsának 2021-es adatai alapján (https:// ec.europa.eu/info/business-economy-euro/economic-and-fiscal-policy-coordination/ financial-assistance-eu/funding-mechanisms-and-facilities/sure_hu)

A SURE program keretében sikerült a tagállamoknak jelentős számú munkahelyet megmenteniük, ugyanakkor nem szabad figyelmen kívül hagyni, hogy ezek a programok csak azoknak a munkavállalóknak nyújtottak segítséget, akik törvényesen, a munka törvénykönyv szerinti foglalkoztatottság alá tartoztak. Azok a dolgozók, akik nem hivatalosan (bejelentés nélkül) végezték a munkájukat, vagy határozott idejű szerződésekkel rendelkeztek, azok számára a program kevésbé adott védettséget az elbocsátás ellen. ${ }^{18}$ A koronavírus-járvány kitörése után az első körben munkájukat elvesztők között számos határozott idejű vagy illegálisan foglalkoztatott munkavállaló volt, ugyanis tőlük tudtak a munkáltatók a legegyszerủbben megválni.

Az egyes európai uniós tagállamok eltérő mértékben támogatták a munkahelyeket. A következő, 3. táblázat a kormányzati intézkedésekkel támogatott munkahelyek százalékos arányát mutatja be. A táblázatban a 2020-as év egyes hónapjaira lebontva mutatjuk be a támogatások arányát, a kapott adatokból látható, hogy május-június-július hónapokban volt a legintenzívebb a kormányzati támogatások aránya, vagyis az első hullám hatásait próbálták az egyes kormányok kiigazítani. A legnagyobb arányú támogatásokat Horvátország, Olaszország és Hollandia adta a munkahelyek megőrzésére a vizsgált időszakban.

18 Colin C. Williams - Aysegul Kayaoglu: COVID-19 and undeclared work: impacts and policy responses in Europe. The Service Industries Journal, 40. (2020), 13-14. 914-931. 


\section{3. táblázat}

Kormányzati intézkedésekkel támogatott munkahelyek aránya 2020 márciusa és decembere között az egyes európai uniós tagállamokban, százalékosan

\begin{tabular}{|c|c|c|c|c|c|c|c|c|c|c|}
\hline & Március & \begin{tabular}{|l|} 
Április \\
\end{tabular} & Május & Június & Július & Augusztus & Szeptember & November & November & December \\
\hline Belgium & $20,66 \%$ & $26,55 \%$ & $21,24 \%$ & $13,00 \%$ & $7,64 \%$ & $6,97 \%$ & $5,53 \%$ & $8,30 \%$ & $10,04 \%$ & $6,04 \%$ \\
\hline Bulgária & $3,45 \%$ & $5,98 \%$ & $5,41 \%$ & $3,11 \%$ & $5,19 \%$ & $5,38 \%$ & $5,10 \%$ & $5,27 \%$ & $5,31 \%$ & $4,97 \%$ \\
\hline \multicolumn{11}{|l|}{$\begin{array}{l}\text { Cseh- } \\
\text { ország }\end{array}$} \\
\hline Dánia & $6,91 \%$ & $8,26 \%$ & $8,03 \%$ & $2,72 \%$ & $1,36 \%$ & $0,06 \%$ & $0,05 \%$ & $0,05 \%$ & $0,01 \%$ & \\
\hline $\begin{array}{l}\text { Német- } \\
\text { ország }\end{array}$ & $7,31 \%$ & $17,69 \%$ & $17,59 \%$ & $13,13 \%$ & $9,89 \%$ & $7,61 \%$ & $6,65 \%$ & $6,01 \%$ & $7,10 \%$ & $7,14 \%$ \\
\hline $\begin{array}{c}\text { Észtor- } \\
\text { szág }\end{array}$ & $5,54 \%$ & $20,26 \%$ & $15,30 \%$ & $5,39 \%$ & & & & & & \\
\hline Írország & $2,98 \%$ & $17,82 \%$ & $19,13 \%$ & $18,33 \%$ & $18,39 \%$ & $16,52 \%$ & & & & \\
\hline $\begin{array}{l}\text { Görög- } \\
\text { ország }\end{array}$ & & $21,04 \%$ & $14,10 \%$ & $4,27 \%$ & $2,99 \%$ & $3,66 \%$ & $4,24 \%$ & $4,58 \%$ & $18,96 \%$ & \\
\hline $\begin{array}{l}\text { Spanyol- } \\
\text { ország }\end{array}$ & & $11,49 \%$ & $13,21 \%$ & $8,93 \%$ & $5,65 \%$ & $4,33 \%$ & $3,32 \%$ & $3,25 \%$ & $1,97 \%$ & $1,20 \%$ \\
\hline $\begin{array}{c}\text { Francia- } \\
\text { ország }\end{array}$ & $27,41 \%$ & $33,69 \%$ & $27,99 \%$ & $14,37 \%$ & $7,74 \%$ & $4,90 \%$ & $5,34 \%$ & $7,29 \%$ & $12,26 \%$ & $9,61 \%$ \\
\hline $\begin{array}{l}\text { Horvát- } \\
\text { ország }\end{array}$ & $38,95 \%$ & $43,04 \%$ & $36,14 \%$ & $5,99 \%$ & $7,09 \%$ & $5,52 \%$ & $1,84 \%$ & $6,57 \%$ & $8,05 \%$ & \\
\hline $\begin{array}{l}\text { Olasz- } \\
\text { ország }\end{array}$ & $31,20 \%$ & $40,20 \%$ & $31,78 \%$ & $20,74 \%$ & $12,96 \%$ & $8,27 \%$ & $7,73 \%$ & $8,79 \%$ & $10,12 \%$ & $5,45 \%$ \\
\hline Ciprus & $30,13 \%$ & $34,97 \%$ & $27,11 \%$ & $7,26 \%$ & $7,56 \%$ & $5,82 \%$ & $6,30 \%$ & & & \\
\hline $\begin{array}{c}\text { Lett- } \\
\text { ország }\end{array}$ & $2,21 \%$ & $4,31 \%$ & $3,89 \%$ & $2,65 \%$ & & & & & & \\
\hline Litvánia & $8,35 \%$ & $13,31 \%$ & $10,81 \%$ & $6,50 \%$ & $1,68 \%$ & $1,09 \%$ & $0,80 \%$ & $0,84 \%$ & $3,63 \%$ & $7,24 \%$ \\
\hline $\begin{array}{c}\text { Luxem- } \\
\text { burg }\end{array}$ & $11,49 \%$ & $24,53 \%$ & $13,58 \%$ & $6,22 \%$ & $2,86 \%$ & $1,79 \%$ & $1,72 \%$ & $1,77 \%$ & $2,30 \%$ & $3,69 \%$ \\
\hline $\begin{array}{c}\text { Magyar- } \\
\text { ország }\end{array}$ & & $0,78 \%$ & $3,01 \%$ & $4,91 \%$ & $5,36 \%$ & $5,48 \%$ & $5,53 \%$ & $5,53 \%$ & & \\
\hline Málta & & & $22,73 \%$ & $32,22 \%$ & & & $30,77 \%$ & & & \\
\hline $\begin{array}{c}\text { Hollan- } \\
\text { dia }\end{array}$ & $30,73 \%$ & $30,37 \%$ & $29,36 \%$ & $29,05 \%$ & $29,16 \%$ & & & & & \\
\hline Ausztria & $14,69 \%$ & $29,55 \%$ & $24,70 \%$ & $13,94 \%$ & $8,57 \%$ & $7,33 \%$ & $4,70 \%$ & $2,73 \%$ & & \\
\hline $\begin{array}{c}\text { Lengyel- } \\
\text { ország }\end{array}$ & & $2,36 \%$ & $3,27 \%$ & $3,04 \%$ & $0,97 \%$ & $0,25 \%$ & $0,08 \%$ & $0,04 \%$ & & \\
\hline $\begin{array}{l}\text { Portu- } \\
\text { gália }\end{array}$ & $4,24 \%$ & $21,63 \%$ & $21,45 \%$ & $13,28 \%$ & $7,25 \%$ & $2,43 \%$ & $1,81 \%$ & & & \\
\hline \multicolumn{11}{|l|}{ Románia } \\
\hline Szlovénia & $13,38 \%$ & $20,55 \%$ & $17,34 \%$ & $7,14 \%$ & $3,85 \%$ & $3,04 \%$ & $2,97 \%$ & $4,17 \%$ & $6,89 \%$ & \\
\hline Szlovákia & $14,36 \%$ & $18,37 \%$ & $16,99 \%$ & $10,82 \%$ & $8,85 \%$ & $7,51 \%$ & $4,78 \%$ & & & \\
\hline $\begin{array}{l}\text { Finn- } \\
\text { ország }\end{array}$ & $2,74 \%$ & $6,92 \%$ & $6,83 \%$ & $5,18 \%$ & $3,76 \%$ & $2,93 \%$ & $2,77 \%$ & & & \\
\hline $\begin{array}{l}\text { Svéd- } \\
\text { ország }\end{array}$ & & $6,04 \%$ & $3,34 \%$ & $0,73 \%$ & $0,23 \%$ & $0,03 \%$ & $0,07 \%$ & $0,09 \%$ & $0,07 \%$ & $0,03 \%$ \\
\hline
\end{tabular}

Forrás: a szerzők szerkesztése az Eurostat 2021-es adatai alapján (https://ec.europa.eu/eurostat/ web/covid-19/data) 


\section{Következtetések}

A saját vizsgálataink során elemeztük az Európai Unió egyes tagállamainak munkaerőpiaci adatait a koronavírus okozta válság elmúlt időszakára vonatkozóan. Az egyes mutatókban negatív tendenciájú értékeket állapítottunk meg, ami összefüggésben van a szakirodalomban leírtakkal, vagyis a koronavírus-válság negatívan hatott az egyes tagállamok munkaerőpiacára, ami csökkenő foglalkoztatottsághoz és emelkedő munkanélküliségi rátához vezetett. Az egyes szektorok foglalkoztatottsági rátájának vizsgálata során is bebizonyosodott, hogy az összes vizsgált szektorra negatív hatással volt a koronavírus-járvány. A legnagyobb arányú negatív hatást a kereskedelem, szállítás és vendéglátás ágazatok szenvedték el. A turizmus egyike azon ágazatoknak, amelyeknek alacsony a válságállósága, a 2020-ban kitört koronavírus-járvány is megmutatta az ágazat sérülékenységét. Azokban az európai uniós országokban, amelyeknek a turizmusból jelentős bevételei származnak, például Görögország, Olaszország, jelentős mértékű volt az ágazat bevételkiesése. ${ }^{19}$

Az előrejelzések szerint az idei évben sem várható javulás, így a munkanélküliségi ráta akár 8,6\%-ra is emelkedhet 2021-ben, ami vélhetően 2022-re 8\%-ra visszarendeződik. ${ }^{20} \mathrm{~A}$ negatív tendenciák kivédésére a tagállamok megpróbálnak segítséget nyújtani az egyes gazdasági szereplőknek, ami a lehívott munkaerőpiaci támogatások összegében és arányában is megmutatkozott.

A munkavégzési módszerek terén is változás figyelhető meg, napjainkban egyre jobban terjed azokban a tagállamokban is a távmunka, ahol ez nem volt korábban jellemző, például a kelet-közép-európai tagállamokban. Ugyanakkor azt is kijelenthetjük, hogy a távmunka nem minden szektor esetében jelent megoldást.

A járvány megjelenése óta az egyes nemzetek kormányai elkötelezettek a járvány és a gazdaságra és a társadalomra gyakorolt negatív következményei leküzdésére, ezáltal az emberek munkahelyének és jövedelmének a megőrzésére. Az európai uniós országok szinte mindegyike jelentős támogatásokat (például kedvezményes hitelek, munkahelymegőrzési támogatások) nyújt a gazdaság szereplőinek ahhoz, hogy sikeresen tudják átvészelni a koronavírus okozta válság negatív gazdasági hatásait.

\section{Felhasznált irodalom}

ACEA: Employment in the EU automotive industry (2020). Online: www.acea.be/statistics/article/employment

19 Francesco Aiello - Graziella Bonanno - Francesco Foglia: On the choice of accommodation type at the time of Covid-19. Some evidence from the Italian tourism sector. Current Issues in Tourism, (2020), 1-5; Gregory T. Papanikos: The Impact of the Covid-19 Pandemic on Greek Tourism. Athens Journal of Tourism, 7. (2020), 2. 87-100.

20 Európai Bizottság: A Bizottság Közleménye az Európai Parlamentnek, a Tanácsnak, az Európai Gazdasági és Szociális Bizottságnakés a Régiók Bizottságának: Turizmus és közlekedés 2020-ban és azon túl COM(2020) 550 végleges (2020a. május 13.).

Európai Tükör 2021/2. 
Aiello, Francesco - Graziella Bonanno - Francesco Foglia: On the choice of accommodation type at the time of Covid-19. Some evidence from the Italian tourism sector. Current Issues in Tourism, (2020), 1-5. Online: https://doi.org/10.1080/13683500.2 020.1846504

Ahrendt, Daphne - Jorge Cabrita - Eleonora Clerici - John Hurley - Tadas Leončikas Massimiliano Mascherini - Sara Riso - Eszter Sándor: Living, working and COVID19: First findings - April 2020. Luxembourg, Publications Office of the European Union, 2020. Online: www.eurofound.europa.eu/sites/default/files/ef_publication/ field_ef_document/ef20059en.pdf

Alipour, Jean-Victor - Harald Fadinger - Jan Schymik: My Home Is my Castle - The Benefits of Working from Home during a Pandemic Crisis: Evidence from Germany. CEPR Discussion Paper 14871, 2020. Online: https://doi.org/10.1016/j.jpubeco.2021.104373

Angeloska, A. - E. Spaller - L. Vasa: Foreign direct investment, digital skills and employability - comparison between Eastern and Western Europe. In Marcel Kordoš: Proceedings of scientific papers from the international scientific conference "The Impact of Industry 4.0 on Job Creation 2020”. Trenčín, Publishing House Alexander Dubček University, 2020. 30-37.

Cheung, Catherine - Miki Takashima - Hyunjung (Helen) Choi - Huijun Yang - Vincent Tung: The impact of COVID-19 pandemic on the psychological needs of tourists: implications for the travel and tourism industry. Journal of Travel \& Tourism Marketing, 38. (2021), 2. 155-166. Online: https://doi.org/10.1080/10548408.2021.1 887055

Európai Bizottság: A Bizottság Közleménye az Európai Parlamentnek, a Tanácsnak, az Európai Gazdasági és Szociális Bizottságnak és a Régiók Bizottságának: Turizmus és közlekedés 2020-ban és azon túl COM(2020) 550 végleges (2020a. május 13.). Online: https:// ec.europa.eu/info/sites/info/files/communication-commission-tourism-transport-2020-and-beyond_hu.pdf

Európai Bizottság: Autumn 2020 Economic Forecast (2020b). Online: https://ec.europa. eu/info/sites/default/files/economy-finance/ecfin_forecast_autumn_2020_overview_en.pdf

Európai Bizottság: Biztonságos utazás Európán belül (2021). Online: https://ec.europa.eu/ info/live-work-travel-eu/coronavirus-response/travel-during-coronavirus-pandemic/eu-helps-reboot-europes-tourism_hu

Európai Tanács - Az Európai Unió Tanácsa: Covid-19: a negatív gazdasági következményekre adott uniós válasz (2021). Online: www.consilium.europa.eu/hu/policies/ coronavirus/covid-19-economy/

Francis, James R.: COVID-19: Implications for Supply Chain Management. Frontiers of Health Services Management, 37. (2020), 1. 33-38. Online: https://doi.org/10.1097/ HAP.0000000000000092

Gyenge, Balázs - Zoltán Máté - Imre Vida - Yuriy Bilan - László Vasa: A New Strategic Marketing Management Model for the Specificities of E-Commerce in the Supply Chain. Journal of Theoretical and Applied Electronic Commerce Research, 16. (2021), 4. 1136-1149. Online: https://doi.org/10.3390/jtaer16040064 
Hoeft, Fabian: The case of sales in the automotive industry during the COVID-19 pandemic. Strategic Change, 30. (2021), 2. 117-125. Online: https://doi.org/10.1002/ jsc. 2395

Nayak, Pallah - Vijay Mishra - Manvendra Singh - Murtaza M. Tambuwala: Impacts and Consequences of COVID-19 Epidemic on Global Economy. Coronaviruses, 2. (2021), 1. 77-88. Online: https://doi.org/10.2174/2666796701999200905094151

Ogbeide, Godwin-Charles: Pandemic (COVID-19) Implications: Recommendations for the Events and Tourism Industry. Events and Tourism Review, 3. (2020), 2. 32-38. Online: https://doi.org/10.18060/24826

Papanikos, Gregory T.: The Impact of the Covid-19 Pandemic on Greek Tourism. Athens Journal of Tourism, 7. (2020), 2. 87-100. Online: https://doi.org/10.30958/ajt.7-2-2

Park, Seejeen - Yoon Jik Cho: Does telework status affect the behavior and perception of supervisors? Examining task behavior and perception in the telework context. The International Journal of Human Resource Management, (2020), 1-26. Online: https:// doi.org/10.1080/09585192.2020.1777183

Rao, Smriti: Beyond the Coronavirus: Understanding Crises of Social Reproduction. Global Labour Journal, 12. (2021), 1. 39-53. Online: https://doi.org/10.15173/glj. v12i1.4307

Unni, J.: Impact of COVID-19 on Informal Economy: The Revival. The Indian Journal of Labour Economics, 63. (2020), 1. 113-118. Online: https://doi.org/10.1007/s41027020-00265-y

Vida, Imre - Endre Spaller - László Vasa: Potential effects of finance 4.0 on the employment in East Africa. Economy and Sociology/Economie si Sociologie, (2020), 2. 29-42. Online: https://doi.org/10.36004/nier.es.2020.2-03

Williams, Colin C. - Aysegul Kayaoglu: COVID-19 and undeclared work: impacts and policy responses in Europe. The Service Industries Journal, 40. (2020), 13-14. 914931. Online: https://doi.org/10.1080/02642069.2020.1757073

Wolski, Marcin - Patricia Wruuck: COVID-19 and the EU labour market: Corporate health matters. Vox.eu, (2020. augusztus 5.). Online: https://voxeu.org/article/ covid-19-and-eu-labour-market-corporate-health-matters

Zoidov, K. K., - A. A. Medkov: Impact of the COVID-19 coronavirus pandemic and its control measures on the functioning of trade routes. Market Economy Problems, (2020), 2. 48-60. Online: https://doi.org/10.33051/2500-2325-2020-2-48-60

Európai Tükör 2021/2. 